\title{
Labelling fashion markets
}

\author{
Patrik Aspers ${ }^{1,2}$ \\ ${ }^{1}$ The Max Planck Institute for the Study of Societies, Paulstr. 3, Cologne, Germany \\ ${ }^{2}$ Department of Sociology, Stockholm University, Stockholm, Sweden
}

\section{MPIfG Journal Article}

Patrik Aspers: Labelling Fashion Markets. In: International Journal of Consumer Studies 32(6), 633 - 638 (2008). Blackwell Science The MPIfG Journal Articles series features articles by MPIfG researchers and visiting scholars published in peer-reviewed journals. Max Planck Institute for the Study of Societies (MPIfG) Cologne | www.mpifg.de

\section{Keywords}

Ethics, fashion, information, labelling, market, political consumption.

\section{Correspondence}

Patrik Aspers, The Max Planck Institute for the Study of Societies, Paulstr. 3, 50676

Cologne, Germany.

E-mail: aspers@mpifg.de

doi: 10.1111/j.1470-6431.2008.00724.x

\begin{abstract}
The present article discusses how an ethical and environmental labelling system can be implemented in fashion garment markets. Consumers act in markets that provide them with more information than their limited cognitive capacity allows them to handle. Ethical and environmental labelling in markets characterized by change, such as the fashion garment market, makes decision-making even more complicated. The ethical and environmental labelling system proposed here is designed to alleviate firms' administrative burden and give consumers more choice. It proposes that information on ethical and environmentally friendly production should be combined to enable consumers to decide whether they want to contribute an extra sum for the item they purchase in the store, which would then be transferred to the workers or an environmental organization. The beneficiaries - garment workers in developing countries and environmental organizations - would decide what to do with the money. This is a simpler and more direct solution than those suggested by scholars and activists trying to solve the problems of 'sweatshops' and the environmental consequences of the production of fashion garments. It also reduces administration compared with existing systems. At the same time, it can be implemented alongside systems based on strict regulation of production.
\end{abstract}

\section{Introduction}

It is clear that consumers are important and that they have power in contemporary market societies (Slater, 1997). The growing debate surrounding the ethical and political dimensions of consumption (D'Souza et al., 2006; Howard and Allen, 2006; Klintman and Boström, 2006), for example on 'sweatshops' (Wilson, 2003, pp. 68-90), should be seen in this light. Consumers are reflective and able to make considered choices (Warde, 1994). The ethical consumer, in contrast to other consumers, cares not only about the price, but also, for example, about how the product was made, by whom and under what conditions, as well as the environmental consequences of production and consumption. Consumers try to include these aspects in consumption decisions, which means that their ends include not only their own individual satisfaction, but, for example, the well-being of workers in garment factories or concern about the environment.

To assist consumers who want to promote particular ends in markets - for example, ethical, environmental or political - it is assumed that they should know about the products and their production conditions. One problem is how to convey this information in final consumer markets so that consumers do not have to be experts in order to make decisions (Jordan et al., 2004). ${ }^{1}$ But even if consumers are reflective and reasonably well informed, it is

${ }^{1}$ When consumers are asked about unethical firms, many mention larger firms, such as H\&M, Shell, Nike and Ikea (Uusitalo and Oksanen, 2004, unlikely that they will know about the production of all the commodities they purchase (Hayek, 1945). This article discusses ways of improving the conditions of workers and diminishing the ways of environmental consequences because of garment production that comply with the current market system and create opportunities for participants in developing countries. ${ }^{2}$

The relationship between the market and morality is a central topic of discussion (Beckert, 2005). The purpose of this article is to consider how markets can deal with the ethical coding or labelling of commodities. Although similar ideas have been voiced previously (Prasad et al., 2004), this text for the first time presents a proposal that does not seek to rearrange the entire garment production industry by imposing various standards. It also applies to other markets in which commodities are subject to rapid change. The article is restricted to a discussion of larger garment retailers (such as The Gap, Marks and Spencer, Topshop, H\&M and Zara). It is only within this market segment of large buyers that firms have the capacity to control their production chain

pp. 218-19). It is more likely, however, that unethical practices will be found among smaller firms operating as importers that cannot afford to employ people to control the firm's Code of Conduct, if such a programme exists at all.

${ }^{2}$ Entering the garment industry has often been the first step in development for many countries as they can benefit from their strongest competitive advantage, namely, relatively cheap labour. 
(Gereffi et al., 2005). The proposal can be used in combination with restrictions on production, as well as with restrictions on the use of natural resources.

\section{What can be signalled in a market?}

Economists (Spence, 2001) see prices as a form of information signal (Mead, 1934, pp. 190-191) that inform actors about products and enable them to navigate and make decisions in the complex market system. But the same price can apply to products of quite different quality; in that case, it is unclear what prices signal, and this is sometimes called an information gap (Spence, 2001, p. 408). Markets characterized by this gap, in which the information that comes with the price tag is not enough to determine the value of the product, cannot rely on price alone. Factors other than price, such as membership of associations and standards, are used to overcome this problem. Many of these signals can easily be imitated by others in the market, however. Trust and local knowledge, therefore, become additional ways of bridging the information gap.

Sociological research has shed some light on this process, and it is clear that producer markets (White, 1981) - that is, markets in which products come out of the production chain (for example, garments, food or cars) - do not operate as predicted by the neoclassical economic model. It has been shown that in producer markets one must separate actors using the notion of identity (White, 2002; Aspers, 2005, 2008). In many producer markets, firms are ranked according to quality or status, and each firm has a market niche, differentiating firms' mix of identity, products, prices and customers. Given this sociological approach to markets, prices are a consequence of the status position (Podolny, 2005) of firms' market identities. Status, however, has the disadvantage that only those who know the status order in a market will be able to interpret this extra information that comes with goods bought in that market.

Labelling of commodities should be seen as yet another way of conveying information to the consumer about the product, in much the same way as status, but without the contextual knowledge that is needed in order to understand what is going on in status markets. The solution is to turn the commodity into an 'ethical' commodity. This information may involve a link between products and consumers, so that the products, for example, are produced in a certain way.

The consumers in these markets are unlikely to know the details of production, however. Moreover, research shows that ethical consumption is problematic, partly because of lack of signalling effects (Uusitalo and Oksanen, 2004). Customers are uncertain not only about the actual conditions of production, but also the different labelling systems (D'Souza et al., 2006). Moreover, each additional label used increases the complexity of the market information, making it more difficult for consumers to make well-informed choices. How, then, can one connect the consumption situation with the conditions of production?

\section{Production of fashion}

All marketers know that it is difficult and often costly to create information links between the product, the producer and the consumer. To establish a credible labelling system in the consumer market takes additional time and effort. The problem of creating labels is even greater in the fashion garment industry, due not only to the structure of the production system, but also to the logic of fashion. Garments are perishable; if they are brought late to the market, there is a risk that they will not sell, or can be sold only at a discount. In response to this, the lead-time of garments has become shorter. This means that the time from deciding to buy or manufacture a garment to having it in stores is shortening and for some commodities is less than a month (Barnes and Lea-Greenwood, 2006). It is important to realize that the logic of the garment industry poses particular problems of supply chain management. In the case of coffee, for example, different production chains may be possible because taste patterns among consumers are stable (Raynolds, 2002). The matter is much more complex in the consumer market for fashion garments, which is characterized by fluctuation and insecurity.

Furthermore, the market share of labelled fashion products, which comply with stricter ethical and environmental demands, still appears to be small (no official statistics are available). In the ethical production chain, which is often characterized by smallscale production, production quality is not easy to maintain at the factory level. This quality problem diminishes the likelihood that consumers will continue to buy from these stores and brands.

In order to increase the possibility of establishing efficient and effective ethical and environmental production chains within this industry, further analysis of the fashion industry is needed. The great variation of fashion products sold in stores demands much from suppliers. As a consequence, it is sometimes possible to find fabrics, and the relevant skills, in only a few countries, or sometimes only in a small industrial district. This means that each retailer must use multiple manufacturers to be able to offer its customers a full range of fashion garments. Quick delivery and product quality are other important demands from retailers that manufacturers must heed. It is moreover costly and difficult to establish a long-term working relationship with the manufacturers. It is even more difficult to do this with firms yet further upstream, namely those that supply the input material needed for garment production. It is easier to establish this kind of relationship if the traded volume is large. This suggests that not only the stores, but the entire supply chain upstream of the retailers must be able to deal with the fluctuations of fashion.

\section{Varieties of labelling systems}

Most of the larger Branded Garment Retailers (BGRs), particularly in the UK and the Nordic countries, have codes of conduct. Most larger firms also prefer to have long-term relations with their suppliers (cf. Lane and Probert, 2006). This means that they also know their manufacturers' conditions of production. Long-term relationships with suppliers can help to control quality and also involve some design input. Firms' codes of conduct are usually based on International Labour Organization (ILO) standards, ${ }^{3}$ which constitute a kind of baseline that BGRs do not fall below. These standards form part of a larger set of demands that BGRs impose on their suppliers to maintain and improve the quality of the garments produced; for example, air-conditioned factories

${ }^{3}$ Several more general standards have been suggested, such as SA8000 and the WRAP (Worldwide Responsible Apparel Production). 
mean not only that working conditions are improved, but also that clothes are less likely to be stained from the workers' perspiration.

One problem with any system that aims to monitor the industry is identification of where the threads of the industrial networks lead. The garment chain, like any global production chain, has numerous links. It is, as already mentioned, difficult to know all the different links and to control or certify that they are ethically and environmentally secure. Subcontracting is used, and sometimes under unpredictable economic and environmental conditions, without legal rights for the worker (Hale and Willis, 2005). How is it possible to combine ethical production with the demands of flexibility to which the fashion industry is subject?

\section{Differentiated production chains}

The first solution is to clearly identify different fashion lines in the stores, with one for ethical - and possibly another for environmental - production, and one for traditional production. This solution implies two additional production chains, with different requirements. It would mean that the fabrics made according to the stricter ethical or environmental demands are different from those that are available for actors in the regular production chain. This solution is feasible, though it comes at an increased cost. To date we have not seen this to a significant extent in the fashion industry, due to the variety of fashion production mentioned above, which demands great flexibility from the entire supply chain. Some garment retailers have ethical or environmentally friendly fashion lines, but these are often restricted to areas in which fashion is not 'cutting-edge,' such as clothes for children, or to fairly standardized products, such as T-shirts.

\section{Current labelling systems}

The second solution is to continue with the current 'labelling' systems. There are two versions: first, the so-called Code of Conduct that one finds in the mainstream industry; and second, the more demanding labels one finds in the alternative segments of the fashion market. ${ }^{4}$ It is plausible to have a system in which all manufacturers must meet the minimal demands set by the retailer, or by an independent organization, such as the ILO. This solution, however, will not meet the more advanced demands of consumers who are more interested in the production conditions of garments and the environmental consequences of garment production. Independent organizations have stores with products that meet the high demands of ethical or environmental organizations. These labels are often strong on environmental and ethical issues, but, even according to themselves, weak on fashion.

Moreover, substantially increasing the demands on market entry may exclude producers in some countries from entering the global fashion industry. Firms that are in the system and able to meet these demands may, in contrast, be made more secure, because of diminished competition 'from below.' In other words, strict demands may enforce a form of 'ethical customs' that creates hurdles for new entrants, restricting opportunities for economic development for people in the least developed countries.

${ }^{4}$ For example, the clean clothes campaign (http://www.cleanclothes.org/, accessed 24 April 2008).
Although the current system of labelling has been successful in the relatively stable coffee market, it is unlikely to be successful in the more volatile fashion industry. A market solution must be sought for the latter.

\section{Towards a solution}

I suggest a minimum standard of ethical and environmental conditions for garment production. Given this ethical baseline standard, consumers would be given the opportunity to pay an extra sum for the item they purchase in the store, the whole of which would go to the workers or an environmental organization. This solution resembles campaigns within the framework of which ' 10 percent' of the price of each item sold is donated to a good cause. According to the solution proposed, all garments would be produced in the same way; in other words, there would not be different production chains, some more 'ethical' than others. Obviously, the one does not exclude the other.

The solution suggested here is that the minimum standards set by the ILO, which many retailers already use, should be kept as the ethical baseline. But consumers should be given the choice of spending money above this minimum level, and thereby benefiting the environment and working conditions further. ${ }^{5}$ The information that consumers need is that the extra money they pay goes to the workers of the plant producing the garment or to an environmental organization, or both, if the consumer supports both ends.

The detailed accounting and quality control systems of the full package solutions that many retailers use means that it is known where and when each item was produced. External accountants, which all large firms must have, can be used to control the transfer of money and provide some form of legitimacy and transparency for the process. This means that it would be relatively easy to send money back to the point of production or to an environmental organization.

\section{Practice}

Two practical aspects of the proposal must be addressed: first, the interface between consumers and garment retailers, and second, the feedback loop that ensures that the money reaches the workers or the environmental organization.

From the perspective of the consumer market, I suggest that the price tag should be coded so that the consumer can choose to support one or both of the particular ends, for example, labelled 'environmental concerns' and 'ethical concerns.' ${ }^{6}$ Hence, while the product is the same, the amount the customer pays and the causes benefited differ. Figure 1 shows the alternatives customers face when buying garments in stores in the four boxes showing

${ }^{5}$ In terms of moral philosophy, this implies a Rawlsian (Rawls, 1971) baseline, but essentially puts its trust in Nozick (1974) potentiality; the baseline secures a minimum standard subject to regulation, but a substantial change can be accomplished only by people's willingness to give money.

${ }^{6}$ An experiment by Prasad et al. (2004) provides support for this idea. In their study, they created a new brand and sold identical products labelled with this brand. Thus, their analysis covers a setting different from what is being proposed here. They assume an entire chain of production organized according to 'Good Working Conditions' (their brand name). 


\begin{tabular}{|l|c|c|}
\hline $\begin{array}{l}\text { Consumer } \\
\text { Concern }\end{array}$ & $\begin{array}{l}\text { Standard } \\
\text { Ethical } \\
\text { Concern }\end{array}$ & $\begin{array}{l}\text { Additional } \\
\text { Ethical } \\
\text { Concern }\end{array}$ \\
\hline $\begin{array}{l}\text { Standard } \\
\text { Environmental } \\
\text { Concern }\end{array}$ & $€ 23$ & $€ 24$ \\
\hline $\begin{array}{l}\text { Additional } \\
\text { Environmental } \\
\text { Concern }\end{array}$ & $€ 24$ & $€ 25$ \\
\hline
\end{tabular}

Figure 1 Example of ethical and environmental concerns and different prices that customers can opt for at the cashier. The lowest sum, €23, means that the buyer gives no extra money for either environmental purposes (to be given to an organization) or factory workers. If the customer, to take another example, decides to give $€ 25$, $€ 1$ goes to the workers who made the garments and $€ 1$ to an organization that works for the improvement of the environment.

prices and colours (shades of grey if printed in black and white). The suggestion is that the endowment should be a small sum, such as one euro or one pound sterling.

The consumer does not have to support any of the ends, or can support one or both of the ends, ethical and environmental. This is done by paying more money at the cashier for the product purchased. If the consumer buys a commodity with an ethical tag, it would be the responsibility of the firm to send the money back to the workers at that factory. To organize this will probably incur transaction costs, but the advantage would be that the extra cost of the garment could be transferred directly to the workers, who would be free to use their share of the 'ethical money' as they please. Although the workers only get a small percentage of the price of the item in the store, in absolute terms, this value is much more than what the manufacturer pays them for producing the item.

The practical details of how workers and organizations will receive money can be discussed here only briefly. The sum that the customer chooses is registered at the point of sale, which means that the ethical and environmental sums generated are known. It would be possible to have the 'ethical sum' generated at one factory distributed among the workers of that factory (according to each worker's share of total wages). Moreover, manufacturers not uncommonly have an open bookkeeping system, so that their buyers know their financial situation. This makes it easier to maintain control over this money to ensure that it reaches the intended recipients. It would, in the end, be the responsibility of the BGRs to make sure that the money is given to the workers. ${ }^{7}$ When it comes to 'green money,' namely, money given to organizations working to improve the environment, it may be appropriate to give

\footnotetext{
${ }^{7}$ The monitoring of working conditions often carried out by NGOs is not central to the solution proposed here (cf. Esbenshade, 2004). See http:// www.amrc.org.hk/ (accessed 24 April 2008) for examples of how working conditions are monitored.
}

\begin{tabular}{|l|c|c|c|}
\hline \multirow{2}{*}{ Issue } & \multicolumn{3}{c|}{ Responsibility of: } \\
\cline { 2 - 4 } & Firm & Consumer & State \\
\hline Paying & & $\mathrm{X}$ & \\
\hline $\begin{array}{l}\text { Administration of the } \\
\text { system }\end{array}$ & $\mathrm{X}$ & & \\
\hline Control & $\mathrm{X}^{*}$ & & \\
\hline
\end{tabular}

Figure 2 Overview of actors' responsibilities according to the proposal. *This control could also be exercised using the BGR's accounting firm or by an independent organization.

the money to a foundation, such as World Wildlife Fund. This sum could then be used for purposes the organization finds best, such as putting pressure on firms - including garment firms - states and consumers to promote environmental ends, or to improve the conditions of production, for example, by ensuring access to water.

To enable consumers to signal how they would like their money to be allocated, if they choose to spend the extra sum, each garment would have a green and a yellow clothing tag (schematically illustrated in Fig. 1), which would be removed by the cashier if the consumer does not pay the extra sum for environmental and/or ethical purposes. If the customer does pay one or both of these additional sums, one or two tags will be retained. Thus, these tags would allow consumers publicly to convey information about the values they support.

In this system, markets would be maintained as the fundamental mechanism of the economy, with added ethical and/or environmental dimensions. This idea is already present in the economics literature (Marshall, 1961, p. 14). Of course, it would be possible to make the extra sum compulsory, and so impose an ethical and environmental tax or fee. This, however, is merely to return to the current system: value added tax is withdrawn from the market and distributed by the state through various agencies, all of which subtract their share. But such a system would serve only to diminish consumers' sense of making a direct difference, and take away their choice and responsibility. Figure 2 shows the different responsibilities according to the alternative proposal offered here. The state is left with no particular task in this system, reflecting the problems faced by states in operating, and in particular in regulating ethics, in the global market arena.

\section{Shortcomings}

The suggestion presented here may face the same problem of credibility as do most labelling systems. It is likely that firms are perceived as having lower credibility than independent bodies and also some states. The market solution means that money-transfer from the buyers to the producers of the garments is organized with the help and at the cost of firms. This cost, however, is limited. Moreover, if people are willing to pay extra to improve the environment or working conditions, this also signals their sentiments to firms, which is likely to have an impact on the construction of the market, how firms market themselves and how they source their garments. 
Can one expect markets to generate the solution proposed here? Empirical research has shown that markets are social constructions embedded in society as well as in other markets (Fligstein, 2001). A market is constantly reconstructing itself and thus involved in processes of change. Given this insight, it is not contradictory to offer proposals to reconstruct the market, especially if one is sensitive to how real markets operate.

The system would not affect everyone in this industry; only those who work for the BGRs' suppliers would be directly affected. The suggested economic transaction implies that workers would get more money, though working conditions themselves may not change directly. Consequently, working conditions may still be harsh and certainly worse than those faced by workers in the West, but the underlying assumption is that it is better to give the workers money and to let them decide how to use it than to impose Western values by implementing codes of conduct (Aspers, 2006). Moreover, the money given for environmental purposes may not directly affect the environment.

The suggested solution does not alter the fundamental logic of markets, namely, that market power is determined by how much money you have. Thus, customers with less purchasing power will never be able to buy the most expensive commodities; they will always be restricted by their budget. They will, however, be able to buy ethical commodities, within the range of their purchasing power.

This approach will not directly influence firms to promote the Western concept of human rights, however. For this purpose, organized political activities, economic boycotts and individual decisions concerning where to buy or not to buy may complement the type of activities discussed here. The approach does not account for the positive effect that mobilization of people in groups and organizations creates. But nor does it exclude such activities.

\section{Summary and conclusion}

One underlying idea of this article - which follows the arguments of, for example, Hayek (1945), von Mises ([1963] 1966), Schütz (1964, pp. 120-134) and others - is that knowledge is unevenly distributed in society and that it is not always efficient to have centralized decision-making (Føllesdal, 2004). In this system, it is essentially the consumers who have to make up their minds. Consumers cannot blame the state, 'the market', or the anonymous 'other' for the poor conditions of workers. One may assume that producers or entrepreneurs steer the economy, but, as von Mises ([1963] 1966, p. 270) points out, 'They are bound to obey unconditionally the captain's orders. The captain is the consumer'. This is perhaps an overstatement in today's world, with huge companies that have the power to influence consumers in many different ways, such as advertisement and fashion blogs. Still, the power of the consumer should not be underestimated, as reflected in the discussion on 'political consumerism' (Micheletti, 2003; Gulbrandsen, 2006, pp. 479-480). Moreover, the customer does not need to know the details of the specific labelling system when he or she buys, which here is reduced to two different colours; it is enough to make a decision to contribute or not to contribute to the different ends, a decision that the consumer can make when facing the cashier.

The solution proposed here is, as it were, a hard test of the willingness of consumers to pay for improving the conditions of workers and the environment. Such a test would be of great interest, however, since surveys seem to overstate the proportion of consumers who will actually pay the extra cost; real world experimental settings indicate that the actual number is much lower (at most one in four - Prasad et al., 2004, p. 72).

\section{Acknowledgements}

The author is grateful for the reviewers' comments and the support of the MPIfG and the Research Centre for Fashion, the Body and Material Cultures at London College of Fashion, at which the author was guest researcher in 2006 .

\section{References}

Aspers, P. (2005) Markets in Fashion: A Phenomenological Approach. Routledge, London, UK.

Aspers, P. (2006) Ethics in global garment market chains. In The Moralization of Markets (ed. by N. Stehr, C. Henning \& B. Weiler), pp. 289-309. Transaction Press, London, UK.

Aspers, P. (2008). Order in garment markets. ACTA Sociologica, 3, 197-202.

Barnes, L. \& Lea-Greenwood, G. (2006) Fast fashioning the supply chain: shaping the research agenda. Journal of Fashion Marketing and Management, 10, 259-271.

Beckert, J. (2005) The Moral Embeddedness of Markets. Max Plank Institute for the Study of Societies Discussion Paper, Cologne, Germany.

D’Souza, C., Taghian, M., Lamb, P. \& Peretiatko, R. (2006) Green decisions: demographics and consumer understanding of environmental labels. International Journal of Consumer Studies, 31, 371-376.

Esbenshade, J. (2004) Monitoring Sweatshops: Workers Consumers, and the Global Apparel Industry. Temple University Press, Philadelphia, PA.

Fligstein, N. (2001) The Architecture of Markets: An Economic Sociology for the Twenty-First Century Capitalist Societies. Princeton University Press, Princeton, NJ.

Føllesdal, A. (2004) Political consumerism as chance and challenge. In Politics, Products and Markets, Exploring Political Consumerism Past and Present (ed. by M. Micheletti, A. Føllesdal \& D. Stolle), pp. 1-20. Transaction Publishers, New Brunswick, NJ.

Gereffi, G., Humphrey, J. \& Sturgeon, T. (2005) The governance of global value chains. Review of International Political Economy, 12, 78-104.

Gulbrandsen, L. (2006) Creating markets for eco-labelling: are consumers insignificant. International Journal of Consumer Studies, 30, 477489.

Hale, A. \& Willis, J. (eds.) (2005) Threads of Labour, Garment Industry Supply Chains from the Workers' Perspective. Blackwell Publishing, Oxford, UK.

Hayek, F. (1945) The use of knowledge in society. The American Economic Review, 35, 519-530.

Howard, P. \& Allen, H. (2006) Beyond organic: consumer interest in new labelling schemes in the central coast of California. International Journal of Consumer Studies, 30, 439-451.

Jordan, A., Wurzel, R., Zito, A. \& Brückner, L. (2004) Consumer responsibility-taking and eco-labelling schemes in Europe. In Politics, Products and Markets, Exploring Political Consumerism Past and Present (ed. by M. Micheletti, A. Føllesdal \& D. Stolle), pp. 161180. Transaction Publishers, New Brunswick, NJ.

Klintman, M. \& Boström, M. (2006) Editorial. International Journal of Consumer Studies, 30, 401-404.

Lane, C. \& Probert, J. (2006) Domestic capabilities and global production networks in the clothing industry: a comparison of German and UK firms' strategies. Socio-Economic Review, 4, 35-67. 
Marshall, A. (1961) Principles of Economics, edited with annotations by C.W. Guillebaud, 2 Volumes. Macmillan and Co., London, UK.

Mead, G. (1934) Mind, Self, and Society, from the Standpoint of a Social Behaviorist. Chicago University Press, Chicago, USA.

Micheletti, M. (2003) Political Virtue and Shopping. Individuals, Consumerism, and Collective Action. Palgrave-Macmillan, New York. von Mises, L. ([1963] 1966) Human Action: A Treatise on Economics. Henry Regnery Company, Chicago, IL.

Nozick, R. (1974) Anarchy, State, and Utopia. Basic Books, Inc., Publishers, New York.

Podolny, J. (2005) Status Signals: A Sociological Study of Market Competition. Princeton University Press, Princeton, NJ.

Prasad, M., Kimeldorf, H., Meyer, R. \& Robinson, I. (2004) Consumers of the world unite: a market-based response to sweatshops. Labor Studies Journal, 29, 57-80.

Rawls, J. (1971) A Theory of Justice. Harvard University Press, Cambridge, MA.

Raynolds, L. (2002) Consumer/Producer links in fair trade coffee networks. Sociologica Ruralis, 42, 404-424.
Schütz, A. (1964) Collected Papers II, Studies in Social Theory. Martinus Nijhoff, The Hague, The Netherlands.

Slater, D. (1997) Consumer Culture and Modernity. Polity Press, Cambridge, UK.

Spence, M. (2001) Signalling in retrospect and the informational structure of markets. In From Les Prix Nobel. The Nobel Prizes (ed. by T. Frängsmyr), pp. 407-444. The Nobel Foundation, Stockholm, Sweden.

Uusitalo, O. \& Oksanen, R. (2004) Ethical consumerism: a view from Finland. International Journal of Consumer Studies, 28, 214-221.

Warde, A. (1994) Consumption, identity-formation and uncertainty. Sociology, 25, 878-898.

White, H. (1981) Where do markets come from. American Journal of Sociology, 87, 517-547.

White, H. (2002) Markets from Networks, Socioeconomic Models of Production. Princeton University Press, Princeton, USA.

Wilson, E. (2003) Adorned in Dreams, Fashion and Modernity. Tauris and $\mathrm{Co}$, London, UK. 